\title{
Bir Dinî İdealin İfade Biçimleri: Râbia el-Adeviyye’den Kalanlar
}

\author{
M. Nedim Tan
}

İstanbul: Pinhan Yayıncılık, 2020, 261 sayfa

ISBN 9786057768186

Son yıllarda ülkemizde tasavvufun teşekkül sürecine yoğunlaşan çalışmalarda nicelik ve nitelik yönünden bir artışın olduğu gözlemlenmektedir. IV. (X.) asrın sonlarına kadar uzatılabilecek bu döneme dair özellikle belli bir kavrama, ${ }^{1}$ şahsa $^{2}$ ya da bölgeye ${ }^{3}$ dair yapılan mikro çalışmalar olduğu gibi, Hacı Bayram Başer’in Şeriat ve Hakikat: Tasavvufun Teşekkül Süreci adlı kilometre taşı niteliğindeki eserinde ${ }^{4}$ olduğu gibi şeriat-hakikat ikilemi, velayet problemi ya da tasavvufi bilginin imkânı gibi belli problematikler ekseninde makro çalışmalar da yapılmaktadır.

Geçtiğimiz aylarda bu çalışmalar zincirine yeni bir halka daha eklendi. M. Nedim Tan’ın erken dönem zühdünü ve züht hareketinden bir Sünnî din ilmi olarak tasavvufa geçişi anlamada kritik bir isim olan Râbia el-Adeviyye (ö. 185/801[?]) üzerine odaklanan, Bir Dinî İdealin İfade Biçimleri: Râbia el-Adeviyye’den Kalanlar başlıklı çalışması erken dönem çalışmalarının çok önemli bir halkası olmaya aday görünüyor.

Tan’ın kitaptaki temel iddiası, sonraki yüzyıllarda oluşan tasavvufi literatürde Basra züht mektebine dair saptanan özelliklerin bu ekolün merkezindeki figürlerden biri olarak Râbia üzerinden aktarıldığıdır. Bu yüzdendir ki

1 Erken dönemde açlık ve evlilik gibi konuları tasavvuf ilmi açısından ele alan şu çalışmalar örnek olarak verilebilir: Sultan Adanır Salihoğlu, Sufilerde Bir Nefs Terbiye Yöntemi Olarak Açlık, İstanbul: HayyKitap, 2019; Emrah Sağmak, İlk Dönem Sufilerinde Evlilik ve Aile Hayatı (yüksek lisans tezi), İstanbul Üniversitesi, 2019.

Örnek olarak bk. Fatma Gedik, Sehl b. Abdullah et-Tüsteri ve Tasavvufi Görüşleri (doktora tezi), Ankara Üniversitesi, 2019; Neşet Bodur, Ebû Nasr Serrâc et-Tûsî ve Tasavvufî Görüşleri (doktora tezi), Ankara Üniversitesi, 2018; İslim Gümüştekin, Horasan'daki Tasavvuf Geleneğinin Bir Şarihi Olarak Ebû Abdurrahman es-Sülemî (ö. 412/1021) ve Tasavvuf Anlayışı (yüksek lisans tezi), Yalova Üniversitesi, 2018; Tuğba Başer, Sehl b. Abdullah et-Tüsterinin (ö. 283/896) Tasavvuf Anlayışı (yüksek lisans tezi), Yalova Üniversitesi, 2017.

3 Erken dönemde belli bölgelerde teşekkül eden tasavvuf ekollerine dair henüz tamamlanmamış bazı tez projeleri yürütüldügünü İSAM’ın ilgili veri tabanından öğreniyoruz. Örnek olarak devam eden şu üç doktora çalışmasını sayabiliriz: Hicret Karaduman, Teşekkül Döneminde Nişabur'da Tasavvuf, Bursa Uludağ Üniversitesi; Mehmet Akif Damar, Tarikatler Öncesi Dönemde Horasan'da Tasavvuf, Dokuz Eylül Üniversitesi; Mahmut Öztekin, Memlükler Döneminde Tasavvuf, Necmettin Erbakan Üniversitesi.

İstanbul: Klasik Yayınları, 2017. 
bir ideal dindarlık tanımı olarak züht, Râbia'da cisimleşmiş ve Râbia ideal bir dindar prototipi olarak sunulmuştur. Yazar bu çözümlemesini kitabın adına da başarılı bir şekilde taşımıştır: Bir Dinî İdealin İfade Biçimleri.

Kitap Türkçe tasavvuf araştırmaları literatüründe yeni bir yazın türü sayılabilecek kadar özgün bir forma sahip. İçerik olarak da II. (VIII.) yüzyıl Basra tasavvufu üzerine alanda bir ilk olma özelliğini taşıyor. Eserin yayımlanmasından kısa bir süre önce Rkia Elaroui Cornell'in Râbia üzerine şimdiye kadarki en kapsamlı çalışma olan kitabı çıkmış olsa da iki eser merkeze aldıkları disiplinler ve vardıkları sonuçlar açısından farklılaşıyor. ${ }^{5}$ Cornell'in çalışması çok başarılı bir teorik zemin sunuyor, ancak anlatı bilim ve mitoloji kapsamında değerlendirilmeye daha uygun bir çalışma hüviyetine sahip. Tan’n eseri ise özelde tasavvuf genelde İslam ilimleri bağlamında değerlendirilmeye daha müsait bir çalışma görünümü arzediyor. Ulaştığı sonuçlar da Râbia üzerine oluşturulan anlatı, mit ya da ikonlardan ziyade II. (VIII.) asır Basra ve çevresinin tasavvufunu anlamaya dönük izler taşıyor.

Tan’ın çalışmasının Türkiyedeki tasavvuf araştırmaları açısından metot anlamında bir ilk olduğunu söylemeliyiz. Zira Tan eserinde Râbia üzerinden tasavvuf tarihini okumaya çalışırken diğer taraftan da tasavvuf tarihi üzerinden Râbia’yı anlamaya çalışıyor (s. 20). Eserin amacını da bu eksende ifade edebiliriz: Râbia üzerine oluşan literatürden kavramsal "motif”leri tespit ederek tasavvuf tarihindeki zihniyet sürekliliğini ortaya koymak (s. 22). Burada her ne kadar interdisipliner bir çalışma yapmış olsa da yazarın esas analitik çözümlemelerini tasavvuf ilminin kavramsallaştırmaları ve metotlarıyla gerçekleştirdiğini söyleyebiliriz. Bunun için de kitapta ilk başvuru kaynaklarının tasavvufi eserler olduğu görülüyor. Fakat yazarın dil, edebiyat ve tarih kaynaklarını da argümanlarını desteklemek için yerli yerince kullandığını eklemeliyiz. ${ }^{6}$

Giriş ve sonuç dışında yedi bölümden oluşan eser literatür değerlendirmesinin ardından Basra çevresinde oluşan tasavvufi hareketler ve özellikle de züht ve muhabbet gibi kavramların arkeolojisiyle başlayıp kronolojik olarak tasavvuf tarihi literatürünün değerlendirilmesiyle devam ediyor. Râbiảnın II. (VIII.) asrın hemen hemen başından sonuna kadar yaşadığı düşünüldügünde yazar, Hasan-1 Basrîden (ö. 110/728) neredeyse Muhâsibî̀ye (ö. 243/857) kadar olan dönemi Râbia üzerinden ele alıyor. Züht bu dönem tasavvufunu

5 Bk. Rkia Elaroui Cornell, Rabi'a from Narrative to Myth: The Many Faces of Islam's Most Famous Woman Saint, Rabia al-Adawiyya, London: Oneworld Academic, 2019.

6 Cornell'in anlatı bilim disiplini üzerine inşa ettiği Râbia anlatılarını analiz ettiği bahsi geçen eseriyle, kendi yapmaya çalıştığı şeyi karşılaştırırken Tan açıkça naratoloji ve mitoloji gibi alanlara girmediğini, çalışmasını tasavvuf tarihi literatürüyle sınırlandırdığını ifade ediyor (s. 133). 
anlamak için merkezî ve kuşatıcı bir kavram olarak ortaya çıkıyor. Önceleri "dünyayı terk" anlamında selbî bir tazammuna sahipken, Râbia anlatılarında gördüğümüz üzere kavram bu dönem Basra’sında ideal dindarlığı işaret eden, bütün güzel ahlakları kuşatıcı bir kavram haline geliyor. Tasavvuf literatüründeki züht anlatıları halihazırda mevcut olan ideallere yaşantılarıyla yeni bağlamlar kazandıran Râbia gibi zâhitler aracılığı ile yaygınlaşıyor (s. 34-39). Bu noktada yazarın, zühdün sadece tasavvuf ilmini değil, bütün dinî disiplinleri ilgilendiren bir kavram olduğunu söylemesi dikkate değer bir nokta olarak kaydedilmeli. Nitekim bir kelam ekolü olarak Mútezile de zühdü önemseyen tutumuyla Basra’da ortaya çıkıyor (s. 47).

Yazara göre Râbia dönemin Basra’sında mevcut dinî arayışları yapıland1ran veya yeni bağlamlara taşıyan kimliği ile tezahür ediyor (s. 63). Râbia’dan sonra oluşan literatürde onunla ilişkilendirilen isimlerin tamamının Basra ve çevresinden olması da önemli bir nokta olarak karşımıza çıkıyor. Anlatılarda Râbiảnın Süfyân es-Sevrîyi (ö. 161/778) tedip eder şekilde temsil edilmesi ise ehl-i tasavvufun diğer ilim sahiplerine yol gösteren bir sûfi tipolojisi çizmek istediklerinin göstergesidir (s. 78). Yazarın en önemli iddialarından birinin Râbiảnın süreç içerisinde sûfi hafızayı taşıyan bir nitelik kazandığıdır (s. 88). Bu da tasavvuf tarihinin onun üzerinden okunmasını mümkün kılar. Sûfi müelliflerin tarihsel olarak gerçek olamayacak -mesela Hasan-1 Basrînnin Râbia’ya öğrenci olması gibi- verileri nakletmeleri ise onların genel olarak naklî ilimlerde mânaya odaklanan mütesahil tutumlarıyla izah edilebilir. Nitekim hadis rivayetinde de sûfiler mâna âleminde Hz. Peygamber'den işittiklerini hadis olarak nakletmelerinin yanı sıra hadislerin mânen rivayetini caiz görmüşler, lafzın ve olayların tam olarak öyle olup olmadığından ziyade kıssadan çıkarılacak hisseye odaklanmışlardır.

Râbia anlatılarında bir dönüm noktasını teşkil eden Ferîdüddin Attâr’’n (ö. 618/1221) Tezkîretü'l-evliyâ’sı kendisine kadar Râbia üzerinden anlatılagelen motiflere ve onun üzerinden taşınan tasavvufi hafızaya estetik bir boyut katmıştır (s. 124). Tan’a göre Attâr, önceki anlatılara tamamen hayal ürünü veriler katmamış, Râbia’nın biyografisindeki boşlukları dönemin Basra’sında oluştuğu düşünülen tasavvufi motiflerle estetik bir biçimde doldurmuştur. Ayrıca o, bu anlatılarında Râbia’yı dönemin Basra tasavvufunun bir temsilcisi olarak görüp tasavvufi kavramları onun üzerinden anlattığı gibi, Hasan-1 Basrîyi Râbiảnın irtibatlı olduğu bütün isimlerin bir temsilcisi olarak seçip meseleleri onun üzerinden anlatmayı tercih etmiştir (s. 145).

II. (VIII.) asır Basra tasavvufu üzerine literatürde henüz oluşmuş bir ikincil kaynak silsilesi olmadığından eserde daha ziyade birincil tasavvuf literatürünün kullanıldığını görüyoruz. Bunu yaparken yazar, Râbia’dan bahseden 
özellikle edebiyat ve dile dair birincil kaynakları da ihmal etmemiş. Eserde kaynak kullanımının çok başarılı olduğu, Râbia üzerine mevcut en kapsam1 ç çalışmayı yapan Cornell'in tespit edemediği noktaları tespit etmiş olmasından da anlaşılıyor. Örneğin Cornell Attâr’n Râbia anlatısında daha evvel hiçbir kaynakta yer almayan uydurma verilerin olduğunu savunurken, Tan bu noktalardan dördünü önceki müelliflerden olan Câhiz (ö. 255/869), Râgıb el-İsfahânî (ö. V/XI. asrın ilk çeyreği), Ebû Ca'fer et-Tabesî (ö. 480/1087) ve İbnü'l-Cevzînin (ö. 597/1201) eserlerinde tespit ediyor. Yazarın Arapça birincil kaynakların yanı sıra Farsça literatürü de çok başarılı şekilde kullanabilmesini, Cornell'in özellikle Attâr'la ilgili verdiği sathî yargılar gibi yargılara ulaşmasını engelleyen bir olumlu özellik olarak zikredebiliriz.

Kitap tasavvuf ilminin kavramsal gelişimini kronolojik bir seyirde Râbia ve ona atfedilenler üzerinden okuması yönüyle oldukça güçlü bir analitik inşa sunuyor. Bundan sonra tasavvufun teşekkül dönemine dair yapılacak çalışmalara çok ciddi bir katkı olarak kuşkusuz ilk başvuru kitapları arasında yerini alacaktır. Yazar araştırmasını tasavvuf tarihi literatürüyle sınırlandırdığını açıkça ifade etmiş olsa da döneme ve bölgeye dair tarih çalışmalarıyla desteklenmesi eserin yaptığı katkıyı arttıracak bir husus olarak zikredilmeli. Eserde bölümlerin numaralandırılmamasını okurun fikrî takibini zorlaştıran, geliştirilebilecek basit bir nokta olarak ekleyelim. Sonraki baskılarda bölümlerin alışılageldik şekilde numaralandırılması okurun belli bir mantıkbilgi inşası içinde ilerlediği hissini pekiştirmek için kolaylaştırıcı bir unsur olacaktır. Bu haliyle okurun birbirinden ayrı müstakil deneme ya da makalelerin bir araya getirildiği bir metni okuduğu hissine kapılması muhtemeldir.

Yoğun dipnotlara ve kitabın kullandığı kavramsal dile bakıldığında eserin sadece konunun uzmanlarına hitap ettiği akla gelse de İslam düşünce tarihinin erken dönemlerini, bir ilim olarak tasavvufun teşekkül sürecini ya da sadece İslam tarihinde meşhur bir kadın olarak Râbia el-Adeviyye’nin temsil ettiklerini merak eden herkesin kitaptan alabileceği şeylerin olduğu söylenebilir. Bunu söylerken okurun asgari düzeyde de olsa tasavvuf kavramlarına aşina olmasının kitabı anlamak adına önemli olduğunu ekleyelim. Eser, İslam düşüncesinin erken dönemine dair literatüre mühim katkılar yapan, bu alanla ilgilenen akademisyenler için de son derece faydalı bir kaynak niteliği taşımaktadır.

Abdullah Taha Orhan, Dr.

Nevşehir Hacı Bektaş Veli Üniversitesi İlahiyat Fakültesi

ORCID 0000-0001-5055-4712

DOI 10.26570/isad.846719 